Article

\title{
Assessment of Morphological Traits, Nutritional and Nutraceutical Composition in Fruits of 18 Apricot cv. Sekerpare Clones
}

\author{
Neva Karatas ${ }^{1}$, Sezai Ercisli ${ }^{2, *(\mathbb{D})}$ and Mehmet Ramazan Bozhuyuk ${ }^{3}$ (D) \\ 1 Department of Nutrition and Dietetics, Faculty of Health Sciences, Ataturk University, \\ Erzurum 25240, Turkey; ngungor@atauni.edu.tr \\ 2 Department of Horticulture, Faculty of Agriculture, Ataturk University, Erzurum 25240, Turkey \\ 3 Department of Plant and Animal Production, Vocational School of Technical Sciences, Igdir University, \\ Igdir 76100, Turkey; mrbozhuyuk@gmail.com \\ * Correspondence: sercisli@gmail.com; Tel.: +90-535-639-5607
}

check for updates

Citation: Karatas, N.; Ercisli, S.; Bozhuyuk, M.R. Assessment of Morphological Traits, Nutritional and Nutraceutical Composition in Fruits of 18 Apricot cv. Sekerpare Clones. Sustainability 2021, 13, 11385. https:/ / doi.org/10.3390/su132011385

Academic Editor: Boris Duralija

Received: 5 August 2021

Accepted: 12 October 2021

Published: 15 October 2021

Publisher's Note: MDPI stays neutral with regard to jurisdictional claims in published maps and institutional affiliations.

Copyright: (c) 2021 by the authors. Licensee MDPI, Basel, Switzerland. This article is an open access article distributed under the terms and conditions of the Creative Commons Attribution (CC BY) license (https:/ / creativecommons.org/licenses/by/ $4.0 /)$.

\begin{abstract}
Apricot (Prunus armeniaca L.) is one of the most important members of Prunus and its trees bears delicious and nutritious fruits during summer months in the temperate zones in the world. Apricot cultivars are propagated asexually which consists of clones. Information on interclonal variations in apricot cultivars can assist us in the selection of better clones from commercial cultivars. We aimed to determine morphological traits (fruit weight, seed weight, kernel weight, flesh/seed ratio, shape index, fruit firmness, color index), nutritional (sugars and organic acids) and nutraceutical (total phenolic, total flavonoids, total carotenoid and antioxidant activity) composition of 18 clones of Sekerpare apricot cultivar grown together in Kagizman district in eastern Turkey. Results showed significant differences among clones concerning most of the morphological traits, nutritional and nutraceutical compositions. Fruit weight, flesh/seed ratio and fruit firmness of clones were in range of $23.14-27.11 \mathrm{~g}, 11.21-13.14$ and $3.88-5.11 \mathrm{~kg} / \mathrm{cm}^{2}$, respectively. Fruit shape index was slightly similar among all clones which was between 0.95 and 1.03 . Citric acid and sucrose were found to be the predominant organic acid and sugar among clones which varied from 728 to $915 \mathrm{mg} / 100 \mathrm{~g}$ and 7.11 to $9.94 \mathrm{~g} / 100 \mathrm{~g}$, respectively. The clone 'KS2' exhibited the highest level of total phenol (67.1 mg gallic acid equivalent per $100 \mathrm{~g})$ and antioxidant activity $(2.16 \mu \mathrm{mol}$ trolox equivalent per g). The study confirmed the diversity among Sekerpare clones and effectiveness of combining morphological, nutritional and nutraceutical analyses in assessment of Şekerpare clones and its use for future pre-breeding programs.
\end{abstract}

Keywords: apricot; Sekerpare; nutraceuticals

\section{Introduction}

Due to suitable climate and soil conditions, Turkey is among the most important fruit producer countries in the world in terms of both the number of fruit species and the amount of production. Turkey ranks first in the world's apricot, fig, hazelnut, sweet cherry and quince production [1]. Nine apricot species and subspecies are known in the world. Among these species, Prunus armeniaca L. is cultivated in main apricot growing countries and spreads over the widest geographical area in the world [2,3]. The origin of apricot, which has been cultivated since ancient times, covers a wide area from Turkistan to Western China. Although apricots are grown geographically almost everywhere in the world, commercial production mostly occurs in countries of southern Europe, north America and north Africa [4].

Apricot can be consumed fresh, dried and canned throughout the year. The fruits of apricots are important for human nutrition, being rich in sugars, organic acids, fiber, vitamin A, vitamin E and potassium [5-9]. 
According to the data of the Food and Agriculture Organization (FAO) based on the year 2018, the amount of apricot production increased 19.5\% compared to the previous year, while the area shows a decrease of $2 \%$ in apricot growing countries. When the data for the last five years (2014-2018) are examined, apricot production increased from 3.3 million tons to 3.8 million tons worldwide, but the production area stayed stable [1]. Turkey is leading world apricot production with a yearly average 750 thousand tons production. The country shares $20 \%$ of the world apricot production and is followed by Uzbekistan (13\%), Iran $(9 \%)$, Algeria (6\%) and Italy $(6 \%)[1]$.

In Turkey, apricot trees are grown mainly in the Aegean region, the Mediterranean region, and in particular the Central and Eastern Anatolia regions. Within the regions, Malatya, Elazig, Erzincan, Kahramanmaras, Kars, Mersin and Iğdır provinces are well known for commercial apricot cultivation and significant portions of the apricots are dried traditionally in these areas. Except for drying, apricots are generally used in the fruit juice industry in Turkey as well $[10,11]$. In recent years, depending on the technological developments, apricot fruits are frozen and become widespread in the market outside of the production period [12].

Each apricot growing region in Turkey has their own apricot cultivars and interregional cultivar transfer generally results in negative results. This is because apricots show low environmental adaptability, and the introduction of foreign germplasm may also result in fluctuating or limited yield. This is associated with differences in fertilization, chilling requirements, late-frost resistance, cold-hardiness, etc. [13]. In Turkey, the cultivar-region relationship is very strong as well in apricots. However, the Şekerpare cultivar can be grown in every region and shows great environmental plasticity. The cultivars are mostly grown in Malatya, Erzincan provinces and Aras valley in Turkey and show variable fruit weight ranging from 20 to $40 \mathrm{~g}[2,4,10,14]$. The cultivar called Shakarpara in Pakistan and India and Shekarpareh in Iran shows great phenotypic variability as well. Phenotypic variation within Sekerpare grown in similar ecological conditions arises from an accumulation of somatic mutations due to vegetative propagation during centuries in different Sekerpare growing countries $[2,15,16]$. The concept of sustainable apricot production can be described as a "three-legged stool", with legs of economic viability, environmental soundness, and social acceptability. Communicating the health benefits of apricot fruit to consumers is an essential ingredient in sustaining apricot product demand, which is a prerequisite for sustainable apricot production. Thus, the cultivar Sekerpare grown in different parts of the world could be adding value for economic viability, environmental soundness, and social acceptability.

Sekerpare is found in most of the apricot growing regions in Turkey and still retains importance and provides interesting economic results in local markets, remaining a popular option for most of the apricot growing regions. This locally adapted cultivar is appreciated for its superior flavor and suitability for both fresh consumption and as a dried product [2].

The Aras valley (Kars-Igdir region) is one of the important apricot growing areas of Turkey. Kagizman district provides almost all of the apricot production in Kars province. In the district, Aprikoz, Sekerpare and wild apricots are grown [17-19]. There are numerous clones of Sekerpare available in the Kagizman district that exhibit differences in key horticultural traits.

Identifying plant varieties is an age-old human endeavor. Historically, morphological traits and later nutritional and nutraceutical characteristics were used to categorize specimens into families, genera, species, cultivars, genotypes, landraces (for perennials: a plant selected from seedlings and asexually re-propagated for its desired characteristics). Thus, varietal characterization based on morphological, nutritional and nutraceutical traits is an important component of fruit tree improvement and breeding [20,21].

Apricot has gained great value in human consumption and commercial importance in recent years, attracting researchers to study its morphological, nutritional and in particular nutraceutical traits. 
Advances in fruit species improvement programmes is only possible when intense and more defined genetic variability exists. The phonological expression of any fruit tree species is mostly governed by two factors viz. heredity and environment. Given the fact that environmental variations can be reduced by growing the identical genotypes under uniform site and climatic conditions, studying genetic parameters is of immense use to obtain superior genotypes of any species.

The present study intended to capture variability across morphological, nutritional and nutraceutical parameters of 18 clones of Sekerpare apricot from a particular similar environmental condition.

\section{Materials and Methods}

\subsection{Plant Samples}

Twenty fruits were harvested from different parts of trees of 18 Sekerpare clones grown together in Kagizman district during July in 2018. Kagizman is located at 40. $1406^{\circ} \mathrm{N}$ and $43.1191^{\circ} \mathrm{E}$ and $1406 \mathrm{~m}$ above mean sea-level. All trees of the 18 Sekerpare clones were found at nearly the same altitude in Kagizman district. All examined trees were pre-selected clones according to higher yield, pest and disease free status and more attractive bigger fruit characteristics. Special attention was given on harvest and fruits were harvested in the same period with the same degree of maturity. A total of 80 fruits per clone were collected and then sorted and cleaned. Mature and healthy fruits were transported to the laboratory and divided into two equal parts for morphological measurements and nutritional and nutraceutical analysis.

\subsection{Morphological Parameters}

A total 40 fruits per clone were used for morphological measurements which included fruit weight, seed weight, kernel weight, flesh/seed ratio, shape index and fruit color coordinates ( $\mathrm{L}$, a and $\mathrm{b}$ values). Fruit weight $(\mathrm{g})$ was measured with a digital scale sensitive to $0.01 \mathrm{~g}$ (Scaltec SPB31). Fruit firmness was determined with a non-destructive Acoustic Firmness Sensor (Aweta B.V., Pijnacker, The Netherlands) expressed as $\mathrm{kg} / \mathrm{cm}^{2}$. Fruit shape index (SI) was calculated with the following equation [22].

$$
\text { SI } \frac{\mathrm{W}+\mathrm{T}}{2 \mathrm{~L}} \text { where } \mathrm{W}: \text { Width, } \mathrm{T}: \text { Thickness and } \mathrm{L}: \text { Length }
$$

Color coordinates $\left(L^{*}, a^{*}\right.$, and $\left.b^{*}\right)$ of fruit skin were determined by a Konica Minolta, CR-400 Plus fruit colorimeter (Konica Minolta, Inc., Chiyoda City, Tokyo, Japan) at four different positions around the equator of the fruits [23].

\subsection{Nutritional and Nutraceutical Composition}

\subsubsection{Sample Preparation and Extraction}

A representative of 40 fruits/clone were randomly selected from the harvested lot at commercial maturity stage. The fruits were then introduced to a High-Speed Pulp Ejection Juicer (Omega Products International, Corona, CA, USA), allowing the separation of pomace and juice. The juice was stored at $-80^{\circ} \mathrm{C}$ until use for nutritional and nutraceutical content. During the analysis, the frozen fruits were taken and thawed to $24-25^{\circ} \mathrm{C}$. A laboratory blender was used to homogenize the fruit samples (100 $\mathrm{g}$ lots of fruits per clone) and a single extraction procedure (taking $3 \mathrm{~g}$ aliquots transferred inside tubes and extracted for $1 \mathrm{~h}$ with $20 \mathrm{~mL}$ buffer including acetone, water (deionized), and acetic acid $(70: 29.5: 0.5 v / v))$ was used [24].

\subsubsection{Organic Acids}

Organic acid composition in fruits of Sekerpare apricot clones was determined by Bevilacqua and Califano [25]. Fruit extracts were obtained by crushing the fruits in cheesecloth. Then, $0.009 \mathrm{~N} \mathrm{H}_{2} \mathrm{SO}_{4}$ was added and shaken for $1 \mathrm{~h}$. The mixture was then centrifuged at 15,000 rpm for $15 \mathrm{~min}$ and the supernatants were filtered twice through a 
$0.45 \mu \mathrm{m}$ membrane filter with a coarse filter (Millipore Millex-HV Hydrophilic PVDF, Millipore, MA, USA) and passed through a SEP-PAK C18 cartridge. Organic acid readings were performed by HPLC using the Aminex column (HPX-87 H, $300 \times 7.8 \mathrm{~mm}$, Bio-Rad Laboratories, Richmond, CA, USA) at 214 and $280 \mathrm{~nm}$ wavelengths in the Agilent package program (Agilent Technologies, Santa Clara, CA, USA). Results are expressed as mg/100 g.

\subsubsection{Determination of Individual Sugars}

For individual sugar (fructose, glucose, and saccharose) analyses, the method of Melgarejo et al. [26] was used. First, homogenized fruits (5 g) were diluted with purified water and homogenate was centrifuged at $6000 \mathrm{rpm}$ for $5 \mathrm{~min}$. Supernatants were filtered through a $0.45 \mu \mathrm{m}$ membrane filter (Iwaki Glass, Jawa Barat, Indonesia) before the analysis. The HPLC analysis was conducted using a PerkinElmer HPLC system with Amino $\mathrm{NH}_{2}$ column, and $85 \%$ acetonitrile $/ 15 \% \mathrm{H}_{2} \mathrm{O}(v / v)$ as a mobile phase. Refractive index detector (RID) was used. Samples were identified and quantified by standards. Results were expressed as $\mathrm{g} / 100 \mathrm{~g} \mathrm{fw}$. To specify the sweetness perception of 40 fruit per clone, their sweetness indices (SI) were calculated according to Roussos et al. [27]. The SI index considers the relative sweetness as a factor of each of the three sugars measured. It is described in the following equation (1): where Glu stands for glucose concentration, Fru for fructose concentration, and Sacch stands for saccharose concentration.

$$
\mathrm{SI}=1.00 \cdot \mathrm{Glu}+2.3 \cdot \mathrm{Fru}+1.35 \cdot \text { Sacch }
$$

\subsubsection{Total Phenol Content}

The total phenolic content (TPC) of the samples was evaluated using the FolinCiocalteu method according to Singleton and Rossi [24]. In this procedure, each extract $(1 \mathrm{~mL})$ was mixed with Folin-Ciocalteu's reagent and water 1:1:20 $(v / v)$. The samples were incubated for $8 \mathrm{~min}$. Then, sodium carbonate $(10 \mathrm{~mL})$ with a concentration of $7 \%$ $(w / v)$ was added. After incubation for $2 \mathrm{~h}$, the absorbance at $750 \mathrm{~nm}$ was measured. The total phenolic content was calculated against the reference standard calibration curve of gallic acid. The TPC was expressed as mg of gallic acid equivalents (GAE) per $100 \mathrm{~g}$ of fresh sample.

\subsubsection{Total Carotenoid Content}

The total carotenoid content was determined by Lichtenthaler [28]. For total carotenoid content, $1 \mathrm{~g}$ of fruit sample was homogenized with $5 \mathrm{~mL}$ of acetone in a cold porcelain mortar in an ice bath. Then, $1 \mathrm{~g}$ of anhydrous sodium sulfate $\left(\mathrm{Na}_{2} \cdot \mathrm{SO}_{4}\right)$ was added to the homogenate, which was elutriated using a paper filter. The filtered solution was made up to $10 \mathrm{~mL}$ with acetone and centrifuged at $2600 \times g$ for $10 \mathrm{~min}$. The upper phase was collected and the absorbance of the solution at 662,645 and $470 \mathrm{~nm}$ was measured. Acetone was used as control. Total carotenoid content is expressed as $\mathrm{mg}$ per $100 \mathrm{~g}$ fresh fruit sample.

\subsubsection{Antioxidant Capacity}

The TEAC value of each sample was detected according to the method described by Rice-Evans et al. [29]. The $7 \mathrm{mM}$ ABTS reagent solutions were prepared and diluted with sodium acetate $\left(\mathrm{C}_{2} \mathrm{H}_{3} \mathrm{NaO}_{2}\right)$ until $0.700 \pm 0.01$ spectrophotometrical absorbance level at $734 \mathrm{~nm}$. Following this, $2.97 \mathrm{~mL}$ buffered solution was mixed with $30 \mu \mathrm{L}$ fruit extract and kept in dark at room temperature for $10 \mathrm{~min}$ and their absorbance levels were measured at $734 \mathrm{~nm}$ using a spectrophotometer. Obtained results were calculated according to TEAC standard calibration curve and expressed as $\mu \mathrm{mol}$ of trolox equivalent/g fresh fruit weight ( $\mu \mathrm{mol} \mathrm{TE} / \mathrm{g} \mathrm{FW})$.

\subsection{Statistical Analysis}

All data were analyzed using SPSS software and procedures. Analysis of variance tables were constructed using the least significant difference (LSD) method at $p<0.05$. 


\section{Results and Discussion}

\subsection{Morphological Traits}

As presented in Table 1 , statistically significant differences $(p<0.05)$ were recorded in fruits of among 18 clones of cv. Sekerpare for most of the morphological traits. Fruit weight and skin color are the most important and distinct external fruit traits in apricots for consumer acceptance. Skin color is a practical and simple indicator with which to instruct harvesters on what to harvest. In addition, consumers in general prefer attractive medium-sized apricot fruits. The flesh/seed ratio is also an important fruit characteristic for apricots [2].

Table 1. Fruit weight, seed weight, kernel weight, flesh/seed ratio, shape index and fruit firmness of 18 Sekerpare clones.

\begin{tabular}{|c|c|c|c|c|c|c|}
\hline Clones & $\begin{array}{l}\text { Fruit } \\
\text { Weight } \\
\text { (g) }\end{array}$ & $\begin{array}{c}\text { Seed } \\
\text { Weight } \\
\text { (g) }\end{array}$ & $\begin{array}{l}\text { Kernel } \\
\text { Weight } \\
\text { (g) }\end{array}$ & $\begin{array}{c}\text { Flesh/Seed } \\
\text { Ratio }\end{array}$ & $\begin{array}{l}\text { Shape } \\
\text { Index }\end{array}$ & $\begin{array}{c}\text { Fruit } \\
\text { Firmness } \\
\left(\mathrm{kg} / \mathrm{cm}^{2}\right)\end{array}$ \\
\hline KS1 & $23.02 c$ & $1.85 \mathrm{bc}$ & $0.78 b c$ & $11.44 \mathrm{bc}$ & $0.98 b$ & $4.96 \mathrm{ab}$ \\
\hline KS2 & $24.56 b c$ & $1.86 \mathrm{bc}$ & 0.68 de & $12.20 \mathrm{ab}$ & $0.99 \mathrm{ab}$ & $4.55 \mathrm{ab}$ \\
\hline KS3 & 27.11a & $2.09 a$ & $0.84 a$ & $11.97 \mathrm{bc}$ & $1.01 \mathrm{ab}$ & $3.98 c$ \\
\hline KS4 & $24.03 b c$ & $1.93 \mathrm{bc}$ & $0.74 \mathrm{~cd}$ & $11.45 b c$ & $1.00 \mathrm{ab}$ & $4.32 b$ \\
\hline KS5 & $26.33 \mathrm{ab}$ & $2.01 \mathrm{ab}$ & $0.79 b$ & $12.09 \mathrm{abc}$ & $0.95 c$ & $3.95 c$ \\
\hline KS6 & $25.18 \mathrm{abc}$ & $1.90 b c$ & $0.75 c$ & $12.25 \mathrm{ab}$ & $1.03 \mathrm{a}$ & $4.20 \mathrm{bc}$ \\
\hline KS7 & $26.55 \mathrm{ab}$ & $2.03 \mathrm{ab}$ & $0.82 \mathrm{ab}$ & $12.08 b$ & $1.00 \mathrm{ab}$ & $4.32 \mathrm{~b}$ \\
\hline KS8 & $25.78 \mathrm{ab}$ & $1.89 b c$ & $0.72 \mathrm{~cd}$ & $12.64 \mathrm{ab}$ & $0.98 b$ & $4.56 \mathrm{ab}$ \\
\hline KS9 & $25.30 \mathrm{~b}$ & $1.85 b c$ & $0.72 \mathrm{~cd}$ & $13.14 \mathrm{a}$ & $1.00 \mathrm{ab}$ & $4.30 \mathrm{~b}$ \\
\hline KS10 & $23.14 c$ & $2.02 \mathrm{ab}$ & $0.74 c$ & $10.46 \mathrm{~cd}$ & $0.98 b$ & 5.11a \\
\hline KS11 & $24.98 b c$ & $1.85 c$ & $0.70 \mathrm{~d}$ & $12.50 \mathrm{ab}$ & $1.03 \mathrm{a}$ & $4.74 \mathrm{ab}$ \\
\hline KS12 & $23.66 b c$ & $2.04 \mathrm{ab}$ & 0.73 cde & $10.60 c$ & $0.97 b c$ & 4.70ab \\
\hline KS13 & $24.58 b c$ & $1.94 \mathrm{abc}$ & $0.81 \mathrm{ab}$ & $11.67 \mathrm{bc}$ & 0.99ab & $4.55 \mathrm{ab}$ \\
\hline KS14 & $23.86 b c$ & $1.83 b c$ & $0.70 \mathrm{~d}$ & $12.04 b$ & $0.96 \mathrm{bc}$ & $4.85 \mathrm{ab}$ \\
\hline KS15 & $23.44 b c$ & $1.92 \mathrm{bc}$ & $0.76 c$ & $11.21 b c$ & $0.98 b$ & $5.02 \mathrm{ab}$ \\
\hline KS16 & $23.40 b c$ & $1.80 \mathrm{~cd}$ & $0.70 \mathrm{~d}$ & $12.00 \mathrm{~b}$ & $0.96 b c$ & $4.80 \mathrm{ab}$ \\
\hline KS17 & $26.13 \mathrm{ab}$ & $1.96 b$ & $0.84 a$ & $12.33 \mathrm{ab}$ & $0.97 \mathrm{abc}$ & $3.88 c$ \\
\hline KS18 & $25.41 \mathrm{ab}$ & $1.92 b c$ & $0.75 c$ & $12.24 \mathrm{ab}$ & $1.00 \mathrm{ab}$ & $4.33 b$ \\
\hline
\end{tabular}

Different letters in the same column indicate significant differences $(p<0.05)$ among clones.

Fruit weight, seed weight and kernel weight of Sekerpare clones differed from each other statistically $(p<0.05)$ which ranged from 23.02 to $27.11,1.80$ to 2.09 and 0.68 to $0.84 \mathrm{~g}$, respectively (Table 1). The variation in fruit and seed weight of the clones was also reflected in the fruit flesh/seed ratio which were in the range of 10.46-13.14.

Shape index and fruit firmness of clones were found between 0.96-1.03 and $3.88-5.11 \mathrm{~kg} / \mathrm{cm}^{2}$ (Table 1). KS3 and KS9 were notable among clones due to relatively high fruit weight and flesh/seed ratio.

Studies on apricots in different parts of Turkey identified variations in apricot fruit weight [18,30-32]. Turkish national apricot cultivars have relatively small fruit size and previous studies indicated this fact. For example, Akin et al. [33] studied main apricot cultivars grown in Malatya and determined fruit weight between 21.16 and $38.24 \mathrm{~g}$. Asma and Ozturk [31] reported that 128 Turkish apricot cultivars that belong to the Iran-Caucasian ecogeographical group generally had low fruit weight (lower than $50 \mathrm{~g}$ ). The authors reported that the fruit weight of only seven apricot cultivars was over $50 \mathrm{~g}$, and the rest of cultivars had lower fruit weight. Karaat and Serce [10] reported fruit weight as $25.12 \mathrm{~g}$ in Cagataybey cultivar and $25.65 \mathrm{~g}$ in Sekerpare cultivar in Malatya which supports our findings. They also found seed weight to be $1.97 \mathrm{~g}$, flesh/seed ratio as 12.02 and fruit firmness as $2.58 \mathrm{~kg} / \mathrm{cm}^{2}$ in cv. Sekerpare. Akca and Asma [34] conducted a clonal selection study on cv. Kabasi that aimed to find better Kabaasi clones with promising horticultural characteristics. They determined 13 promising clones among 450 Kabaasi trees. Fruit weight, seed weight, kernel weight and flesh/seed ratio were found between 31.81 and 
$60.91 \mathrm{~g}, 2.35-3.01 \mathrm{~g}, 0.52-0.98 \mathrm{~g}$ and $12.38-16.64$, respectively, indicating similarities with our study. Previously, the flesh/seed ratios of the foreign apricot cultivars grown in Turkey varied between 8.9 and 21.8 [35,36]. In the literature, the shape index of apricots was reported between 0.91 and 1.09 [37,38]. In apricots, if fruit shape index values are found around 1, fruit tend to have a round shape. The Sekerpare cultivar in general gave round shaped fruits while if these values are higher than 1 , fruits correspond to ovoid shape.

$L^{*}, a^{*}$ and $b^{*}$ color coordinates of clones are given in Table 2 and it was found that the $L^{*}, a^{*}$ and $b^{*}$ values of the Sekerpare clones significantly differed from each other at $p<0.05$ (Table 2).

Table 2. Fruit skin color parameters of 18 Sekerpare clones.

\begin{tabular}{cccccc}
\hline Clones & $\boldsymbol{L}^{*}$ & \multicolumn{1}{c}{$\boldsymbol{a}^{*}$} & $\boldsymbol{b}^{*}$ & Ground Color & Red Blushed Skin \\
\hline KS1 & $61.21 \mathrm{~cd}$ & $11.38 \mathrm{~d}$ & $42.56 \mathrm{ab}$ & Yellow & Absent \\
KS2 & $63.45 \mathrm{bc}$ & $14.29 \mathrm{bc}$ & $40.14 \mathrm{c}$ & Yellow & Present \\
KS3 & $59.89 \mathrm{de}$ & $14.90 \mathrm{bc}$ & $44.13 \mathrm{a}$ & Dark yellow & Present \\
KS4 & $63.11 \mathrm{bc}$ & $15.57 \mathrm{ab}$ & $39.88 \mathrm{~cd}$ & Yellow & Present \\
KS5 & $60.18 \mathrm{~d}$ & $15.39 \mathrm{~b}$ & $40.55 \mathrm{bc}$ & Light orange & Present \\
KS6 & $64.10 \mathrm{~b}$ & $12.55 \mathrm{~cd}$ & $38.15 \mathrm{~d}$ & Light yellow & Absent \\
KS7 & $63.23 \mathrm{bc}$ & $10.67 \mathrm{de}$ & $41.23 \mathrm{bc}$ & Yellow & Absent \\
KS8 & $56.15 \mathrm{f}$ & $14.44 \mathrm{bc}$ & $43.32 \mathrm{ab}$ & Dark yellow & Present \\
KS9 & $58.33 \mathrm{de}$ & $10.14 \mathrm{def}$ & $42.56 \mathrm{ab}$ & Dark yellow & Absent \\
KS10 & $65.41 \mathrm{ab}$ & $12.80 \mathrm{~cd}$ & $37.45 \mathrm{de}$ & Yellow & Absent \\
KS11 & $58.45 \mathrm{de}$ & $13.38 \mathrm{c}$ & $37.89 \mathrm{de}$ & Light orange & Present \\
KS12 & $57.10 \mathrm{ef}$ & $17.12 \mathrm{a}$ & $39.11 \mathrm{~cd}$ & Light orange & Present \\
KS13 & $64.96 \mathrm{ab}$ & $10.77 \mathrm{de}$ & $40.15 \mathrm{c}$ & Yellow & Present \\
KS14 & $66.32 \mathrm{a}$ & $14.20 \mathrm{bc}$ & $38.68 \mathrm{~cd}$ & Light yellow & Present \\
KS15 & $63.50 \mathrm{bc}$ & $16.41 \mathrm{ab}$ & $43.33 \mathrm{ab}$ & Dark yellow & Absent \\
KS16 & $60.25 \mathrm{~d}$ & $11.00 \mathrm{de}$ & $41.22 \mathrm{bc}$ & Yellow & Absent \\
KS17 & $62.27 \mathrm{c}$ & $10.70 \mathrm{de}$ & $43.09 \mathrm{ab}$ & Dark yellow & Present \\
KS18 & $58.00 \mathrm{e}$ & $12.07 \mathrm{~cd}$ & $42.25 \mathrm{~b}$ & Light orange & Absent \\
\hline
\end{tabular}

Different letters in the same column indicate significant differences $(p<0.05)$ among clones.

Color is of primary importance for consumers in the judgment of different fruit groups and accepted as one of the important quality attributes. Lightness $\left(L^{*}\right)$, red/greenness $\left(a^{*}\right)$, and yellow/blueness $\left(b^{*}\right)$ values of the 18 clones of cv. Sekerpare are shown in Table 2. The highest $L^{*}$ values were observed in clones KS14 as 66.32 and followed by KS10 (65.41) while KS18 had the lowest $L^{*}$ values (58.00) compared to the other clones. The lightness $\left(L^{*}\right)$ was dependent on exposure to sun [39]. Higher $a^{*}$ and $b^{*}$ values were observed in KS12 (17.12) and 44.13 (KS3). The chromaticity coordinate $a^{*}$ is the most important factor of maturity appearance describing color of the fruit. The intensity of red color normally indicates full maturity and ripeness [40]. Karaat [41] indicated $L^{*}, a^{*}$ and $b^{*}$ values in Sekerpare fruit as 64.17, 14.07 and 42.27, respectively, which is in agreement with our results. Karatas and Sengul [4] reported $L^{*}, a^{*}$ and $b^{*}$ values as 48.66, 19.41 and 19.72 in Sekerpare fruits which indicated differences with our study. In India, $L^{*}, a^{*}$ and $b^{*}$ values of cv. Shakarpara (Sekerpare) were 71.51, 1.03 and 40.56, respectively [16]. These results also reveal that Sekerpare is probably the name of a group of apricots because quite diverse results were obtained from different countries even in the same countries and also strong clonal variation is evident because different clones of the cultivar show significant variation in color values as well.

Among 18 clones, seven had yellow ground color, five clones had dark yellow ground color, four clones had light orange ground color and two clones had light yellow ground color (Table 2).

The majority of clones had red blushed skin and eight clones lacked red blushed skin development (Table 2). The majority of apricot (Prunus armeniaca L.) cultivars display orange or yellow background skin, whereas some cultivars are particularly preferred by consumers because of their red blushed skin on the background. Anthocyanins are 
responsible for the blushed skin of apricots and the PaMYB10 gene was found as a positive regulator of anthocyanin biosynthesis in apricots and demonstrates that blush formation depends on light [42]. Apricots with a blush on orange or yellow skin are becoming more and more popular in the market due to their colorful appearance and excellent nutritional value [43].

\subsection{Nutritional Traits}

\subsubsection{Organic Acids}

The results on organic acid content in fruits of 18 clones of cv. Sekerpare apricots are reported in Table 3. The order of organic acid depending on their content was in descending order citric $>$ malic $>$ ascorbic $>$ tartaric for all clones. Citric acid was the predominant organic acid for all studied clones that ranged from 728 to $915 \mathrm{mg} / 100 \mathrm{~g}$. Malic acid and tartaric acid content of 18 Sekerpare clones were in range of 261-452 and $2.8-5.7 \mathrm{mg} / 100 \mathrm{~g}$, respectively (Table 3). Ascorbic acid was identified in all clones from $13.9 \mathrm{mg}$ to $18.6 \mathrm{mg} / 100 \mathrm{~g}$ and this indicates that apricot fruits contain a moderate level of ascorbic acid among fruit species. Organic acid results also indicated that citric, malic, tartaric and ascorbic acid concentrations are greatly varied among clones $(p<0.05)$. Organic acids are of increasing interest because of their role in plant physiology as cofactors, buffering agents, etc. [44]. The organic acid content and profile of fruit species differs depending on species, cultivars, accessions, etc. Alajil et al. [16] showed that citric acid comprised approximately 55\% of the organic acids in apricot fruits and ranged from 550 to $1170 \mathrm{mg} / 100 \mathrm{~g}$, followed by malic acid, which comprised approximately $25 \%$ of the organic acids and ranged from 400 to $1430 \mathrm{mg} / 100 \mathrm{~g}$. Some organic acids have an antioxidant role (tartaric, malic and citric acids). Fruit acids that allow nutrient digestion and stimulate blood circulation are considered among the quality parameters of apricot fruits. Numerous studies have quantified and detailed the organic acid content of apricot fruits and there have been differences between them due to the species, location, used methods, sampling periods, etc. [16,44-52]. Fan et al. [49] showed that malic acid was mainly responsible for sourness of apricots, although malic acid was not the prominent organic acid in all apricot cultivars. It has also been reported that malic acid has an apparent acidic taste compared to citric acid or other organic acids in fruit [53].

Table 3. Organic acids in fruits of 18 Sekerpare clones (mg/100 g).

\begin{tabular}{|c|c|c|c|c|}
\hline Clones & Citric Acid & Malic Acid & Ascorbic Acid & Tartaric Acid \\
\hline KS1 & $880 \mathrm{ab}$ & 275de & $17.2 \mathrm{ab}$ & $5.0 \mathrm{ab}$ \\
\hline KS2 & $915 a$ & $261 \mathrm{e}$ & $18.0 \mathrm{ab}$ & $3.2 \mathrm{~cd}$ \\
\hline KS3 & $885 a b$ & 296de & $18.6 a$ & $3.6 c$ \\
\hline KS4 & $904 \mathrm{ab}$ & $405 b c$ & 17.6ab & $4.4 \mathrm{bc}$ \\
\hline KS5 & $822 b c$ & $350 \mathrm{~cd}$ & $15.0 \mathrm{bc}$ & $4.0 \mathrm{bc}$ \\
\hline KS6 & $816 b c$ & $427 \mathrm{ab}$ & $15.8 \mathrm{bc}$ & $5.7 \mathrm{a}$ \\
\hline KS7 & $734 \mathrm{~cd}$ & $304 d$ & $14.0 \mathrm{c}$ & $5.0 \mathrm{ab}$ \\
\hline KS8 & $829 b c$ & $380 b c$ & $15.1 b c$ & $2.8 \mathrm{~cd}$ \\
\hline KS9 & $728 d$ & $369 c$ & $14.7 \mathrm{bc}$ & $4.0 \mathrm{bc}$ \\
\hline KS10 & $763 \mathrm{~cd}$ & $387 \mathrm{bc}$ & $16.0 \mathrm{~b}$ & $5.0 \mathrm{ab}$ \\
\hline KS11 & $838 b$ & $344 \mathrm{~cd}$ & $13.9 c$ & $3.6 c$ \\
\hline KS12 & $874 a b$ & $395 b c$ & $18.4 \mathrm{ab}$ & $4.7 \mathrm{~b}$ \\
\hline KS13 & $769 c$ & $360 \mathrm{~cd}$ & $17.9 \mathrm{ab}$ & $5.5 \mathrm{ab}$ \\
\hline KS14 & $745 \mathrm{~cd}$ & $452 \mathrm{a}$ & $15.7 b c$ & $4.2 b c$ \\
\hline KS15 & $796 b c$ & $412 b$ & $18.0 \mathrm{ab}$ & $4.0 \mathrm{bc}$ \\
\hline KS16 & $778 c$ & $435 \mathrm{ab}$ & $18.2 \mathrm{ab}$ & $3.4 \mathrm{c}$ \\
\hline KS17 & $810 b c$ & $365 \mathrm{~cd}$ & $14.0 \mathrm{c}$ & $3.2 \mathrm{~cd}$ \\
\hline KS18 & $785 \mathrm{bc}$ & $422 \mathrm{ab}$ & $14.4 b c$ & $3.6 c$ \\
\hline
\end{tabular}




\subsubsection{Individual Sugars and Sweetness Indices}

Sugar content in different Sekerpare clones is shown in Table 4. The dominant sugar was sucrose in 18 clones that ranged from 7.11 to $9.94 \mathrm{mg} / 100 \mathrm{~g}$, followed by glucose in the range of 2.03-3.31 g/100 g, respectively. Fructose content of fruits was relatively lower and found between 0.78 and $1.05 \mathrm{~g} / 100 \mathrm{~g}$ (Table 4). Overall, the highest sucrose, glucose and fructose contents were found in KS17, KS1, KS3 and KS4 clones, respectively. Sweetness index (SI) was obtained between 13.35 (KS13) and 18.46 (KS17). Alajil et al. [16] used a number of apricots including Sekerpare in nutritional analysis and reported that sucrose was the dominant sugar, accounting for more than $63 \%$ of total sugars and ranged from 4.15 to $10.13 \mathrm{~g} / 100 \mathrm{~g}$, glucose contributed about $22 \%$ of total sugars and ranged from 2.28 to $4.31 \mathrm{~g} / 100 \mathrm{~g}$, and fructose contributed about $15 \%$ of total sugars and ranged from 1.22 to $4.19 \mathrm{~g} / 100 \mathrm{~g}$ which shows parallel values with our study. Saridas and Agcam [44] examined individual sugars and organic acids in Agerik and Teberze apricot cultivars and reported that both contents change greatly according to cultivars. They reported sucrose, glucose and fructose content between 5.33 and 8.57, 1.90 and 2.95 and 0.60 and $0.88 \mathrm{~g} / 100 \mathrm{~g}$, respectively. Furthermore, the composition of individual sugars in the current study agrees with that documented by Akin et al. [33] for different Turkish apricot cultivars. İmrak et al. [45] found that the dominant sugar in apricot fruits was sucrose. Karataş and Sengul [4] reported sucrose content between 1.83 and $3.97 \mathrm{~g} / 100 \mathrm{~g}$ in main apricot cultivars sampled in Malatya province in Turkey. Su et al. [46] used local apricots in sugar analysis and found that sucrose was the main sugar. Individual sugars differ in sweetness, with fructose perceived as sweeter than sucrose and sucrose perceived as sweeter than glucose [27]. The sweetness is important to apricot consumers and breeders, and it also leads to market acceptance of the fruit [47].

Table 4. Individual sugars (g/100 g) and sweetness indices (SI) in fruits of 18 Sekerpare clones.

\begin{tabular}{|c|c|c|c|c|}
\hline Clones & Sucrose & Glucose & Fructose & $\begin{array}{c}\text { Sweetness } \\
\text { Index (SI) }\end{array}$ \\
\hline KS1 & $9.06 \mathrm{ab}$ & $3.24 \mathrm{a}$ & $0.95 \mathrm{ab}$ & $17.66 \mathrm{ab}$ \\
\hline KS2 & $7.67 \mathrm{bc}$ & $2.70 b c$ & $0.89 \mathrm{~b}$ & $15.10 \mathrm{bc}$ \\
\hline KS3 & $8.23 b c$ & $3.02 \mathrm{ab}$ & $1.05 \mathrm{ab}$ & $16.55 b$ \\
\hline $\mathrm{KS} 4$ & $7.77 \mathrm{bc}$ & $2.90 \mathrm{abc}$ & $1.09 \mathrm{a}$ & $15.90 \mathrm{bc}$ \\
\hline KS5 & $8.11 b c$ & $3.10 \mathrm{ab}$ & $0.86 \mathrm{bc}$ & $16.03 \mathrm{bc}$ \\
\hline KS6 & $7.90 \mathrm{bc}$ & $2.22 \mathrm{~cd}$ & $0.67 c$ & $14.43 \mathrm{~cd}$ \\
\hline KS7 & $7.61 b c$ & $2.03 \mathrm{~d}$ & $0.78 b c$ & $14.09 \mathrm{~cd}$ \\
\hline KS8 & $8.10 \mathrm{bc}$ & $2.78 b c$ & $0.99 \mathrm{ab}$ & $16.00 \mathrm{bc}$ \\
\hline KS9 & $8.40 b$ & $2.55 \mathrm{bc}$ & $0.80 \mathrm{bc}$ & $15.73 b c$ \\
\hline KS10 & $7.86 \mathrm{bc}$ & $3.20 \mathrm{a}$ & $1.02 \mathrm{ab}$ & $16.16 \mathrm{bc}$ \\
\hline KS11 & $8.33 b$ & 3.31a & $0.90 \mathrm{~b}$ & $16.63 b$ \\
\hline KS12 & $7.85 \mathrm{bc}$ & $2.39 \mathrm{bcd}$ & $1.00 \mathrm{ab}$ & $15.29 b c$ \\
\hline KS13 & 7.11c & $2.14 \mathrm{~cd}$ & $0.70 \mathrm{c}$ & $13.35 d$ \\
\hline KS14 & $7.56 \mathrm{bc}$ & $2.29 \mathrm{~cd}$ & $0.82 b c$ & $14.39 \mathrm{~cd}$ \\
\hline KS15 & $8.06 \mathrm{bc}$ & $2.63 \mathrm{bc}$ & $1.02 \mathrm{ab}$ & $15.78 b c$ \\
\hline KS16 & $7.37 \mathrm{bc}$ & $2.55 b c$ & $1.05 \mathrm{ab}$ & $14.92 \mathrm{c}$ \\
\hline KS17 & $9.94 a$ & $2.85 b$ & $0.95 \mathrm{ab}$ & $18.46 \mathrm{a}$ \\
\hline KS18 & $9.12 \mathrm{ab}$ & $2.47 \mathrm{c}$ & $0.75 b c$ & $16.33 \mathrm{bc}$ \\
\hline
\end{tabular}

Different letters in the same column indicate significant differences $(p<0.05)$ among clones.

The sweetness index (SI) in fruits of Sekerpare clones ranged from 13.35 to 18.46 (Table 3). Previously, the sweetness index (SI) ranged from 13.58 to 22.30 in apricot fruits grown in India and Shakarpara reported a SI of about 13.58 [16], indicating lower values than our study. In Greece, SIs were found between 8.16 and 11.25 among apricot cultivars [27]. Our findings are consistent with those published SIs for Spanish apricot genotypes ranging from 8.5 to 15.9 [48]. Despite the fact that SI determines taste, the final perception of fruit sweetness is influenced by the presence of other compounds such as phenolics and other aroma compounds [49]. 


\subsection{Nutraceutical Traits}

Total Phenolic Content, Total Flavonoids, Total Carotenoids and Antioxidant Activity

Table 5 shows total phenolic, total flavonoid, total carotenoid content and antioxidant activity in fruits of 18 clones of cv. Sekerpare. We found statistically significant differences among clones in terms all nutraceutical traits at 0.05 level (Table 5).

Table 5. Nutraceuticals in fruits of 18 Sekerpare clones (fresh weight basis).

\begin{tabular}{|c|c|c|c|c|}
\hline Clones & $\begin{array}{l}\text { Total Phenolic Content } \\
\text { (mg GAE/100 g) }\end{array}$ & $\begin{array}{c}\text { TEAC } \\
(\mu \mathrm{mol} \mathrm{TE} / \mathrm{g})\end{array}$ & $\begin{array}{l}\text { Total Flavonoids } \\
\text { (mg CE/100 g) }\end{array}$ & $\begin{array}{l}\text { Total Carotenoid } \\
(\mathrm{mg} / \mathbf{1 0 0} \mathrm{g})\end{array}$ \\
\hline KS1 & $58.4 \mathrm{c}$ & $1.96 \mathrm{bc}$ & $11.9 \mathrm{c}$ & $7.80 \mathrm{e}$ \\
\hline KS2 & $67.1 \mathrm{a}$ & $2.16 a$ & $13.8 \mathrm{ab}$ & $7.72 \mathrm{e}$ \\
\hline KS3 & $56.0 \mathrm{~cd}$ & $1.92 b c$ & $12.7 \mathrm{abc}$ & $9.30 \mathrm{bc}$ \\
\hline KS4 & $61.3 b c$ & $2.06 \mathrm{ab}$ & $10.5 \mathrm{de}$ & $8.84 c$ \\
\hline KS5 & $59.3 b c$ & $1.96 \mathrm{bc}$ & $9.3 \mathrm{ef}$ & $10.05 \mathrm{ab}$ \\
\hline KS6 & $64.4 \mathrm{ab}$ & $2.12 \mathrm{ab}$ & $12.9 b$ & $8.28 \mathrm{~cd}$ \\
\hline KS7 & $62.0 \mathrm{~b}$ & $2.09 \mathrm{ab}$ & $12.1 \mathrm{bc}$ & $8.65 b c$ \\
\hline KS8 & $58.0 \mathrm{c}$ & $1.94 b c$ & 10.5de & $9.25 \mathrm{abc}$ \\
\hline KS9 & $49.9 \mathrm{e}$ & $1.88 \mathrm{bc}$ & $9.8 \mathrm{e}$ & $9.10 b c$ \\
\hline KS10 & $55.0 \mathrm{~d}$ & $1.90 \mathrm{bc}$ & $9.2 \mathrm{ef}$ & $8.58 \mathrm{~cd}$ \\
\hline KS11 & $59.0 \mathrm{bc}$ & $1.98 \mathrm{bc}$ & $10.9 \mathrm{~d}$ & $8.51 \mathrm{~cd}$ \\
\hline KS12 & 63.0ab & 2.09ab & 13.3ab & $10.13 a$ \\
\hline KS13 & $61.0 \mathrm{bc}$ & $2.04 \mathrm{ab}$ & $11.7 \mathrm{abc}$ & $9.41 b$ \\
\hline KS14 & $58.9 \mathrm{bc}$ & $1.99 b c$ & $13.6 \mathrm{ab}$ & $8.44 \mathrm{~cd}$ \\
\hline KS15 & $49.5 \mathrm{e}$ & $1.86 c$ & $11.4 \mathrm{bc}$ & $8.16 \mathrm{~d}$ \\
\hline KS16 & $57.2 \mathrm{~cd}$ & $1.92 b c$ & $10.5 \mathrm{de}$ & $8.95 b c$ \\
\hline KS17 & $60.4 b c$ & $2.01 \mathrm{~b}$ & $11.4 \mathrm{~cd}$ & $8.40 \mathrm{~cd}$ \\
\hline KS18 & $60.7 b c$ & $2.04 \mathrm{ab}$ & $14.1 \mathrm{a}$ & $8.88 \mathrm{c}$ \\
\hline
\end{tabular}

Different letters in the same column indicate significant differences $(p<0.05)$ among clones.

As mentioned in Table 5, total phenolic content was found between 49.5 and $67.1 \mathrm{mg}$ GAE/100 $\mathrm{g}$ fresh weight basis. Saeed et al. [54] used fruits of eight apricot cultivars sampled from Pakistan and reported total phenolic content between 50 and $220 \mathrm{mg}$ GAE/100 g FW indicating higher values than our results. Gecer et al. [18] used a number of wild apricots and cv. Aprikoz and found total phenolic content between 34.2 and $52.8 \mathrm{mg}$ GAE/100 $\mathrm{g}$ which is in accordance with our study. In Hungary, a large number of apricot cultivars were used in nutraceutical analysis and total phenolic content greatly varied among cultivars from 12.0 to 89.0 mg GAE/100 g [7]. In Turkey, Karaat and Serce [10] used main apricot cultivars in Malatya and reported total phenolic content between 35.1 and $90.7 \mathrm{mg}$ GAE/100 g. In the Mediterranean region in Turkey, apricots show total phenolic content between 14.4 and $177.1 \mathrm{mg} \mathrm{GAE} / 100 \mathrm{~g}$, with a mean value of $64.4 \mathrm{mg}$ GAE/100 $\mathrm{g}$ indicating similarities with our samples [55]. Alajil et al. [16] reported total phenolic content among apricots, ranging from 25.31 (Shakarpara) to $89.95 \mathrm{mg}$ GAE/100 g (Roxana). Wani et al. [56] and Leccese et al. [57] previously reported similar findings in apricots grown in India and Italy, respectively.

Total flavonoids were in range of 9.2-14.1 mg CE/100 g (Table 5). Saeed et al. [54] reported total flavonoids between 48 and $382 \mathrm{mg}$ QE/100 $\mathrm{g}$ on fresh weight basis in apricots indicating higher values than our results. Alajil et al. [16] found that total flavonoid amounts in apricot genotypes ranged from 5.00 to $15.46 \mathrm{mg} \mathrm{CE} / 100 \mathrm{~g}$ which indicated good agreement with our study. Our results are also consistent with those reported by Carbone et al. [58], who reported total flavonoid content (TFC) ranging from 1.9 to $12.0 \mathrm{mg}$ $\mathrm{CE} / 100 \mathrm{~g}$ for different apricot genotypes. Kafkaletou et al. [59] and Wani et al. [56] found TFC values ranging from 16.87 to 41.42 and 12.2 to $36.2 \mathrm{mg} / 100 \mathrm{~g}$ in apricot genotypes grown in Greece and India, respectively. Phenolics and flavonoids are essential measures of nutraceutical quality and have been linked to the treatment of a variety of chronic diseases, including cancer, cardiovascular disease, and neurodegeneration [60-64]. 
Total carotenoid content of 18 apricot clones of cv. Sekerpare were found between 7.72 and $10.13 \mathrm{mg} / 100$. Gecer et al. [18] reported total carotenoid content ranged from 1.1 to $12.5 \mathrm{mg} / 100 \mathrm{~g}$ of edible portion in wild apricots and cv. Aprikoz. Ruiz et al. [65] found total carotenoid content between 1.5 and $16.5 \mathrm{mg} / 100 \mathrm{~g}$ among a large number of apricot cultivars in Spain. Shemesh et al. [66] found total carotenoid content between 0.5 and $9.5 \mathrm{mg} / 100 \mathrm{~g}$ among 113 apricot cultivars in Israel. These studies are in harmony with our results. The content and composition of carotenoids in apricots determine their fruit color. Apricots are high in carotenoids, which influence the color and visual appearance of the fruit; the color of the fruit can vary from yellow to orange depending on the carotenoids content [67]. Carotenoids are also essential dietary sources of vitamin A.

The antioxidant activity determined by TEAC assay in fruits of the 18 Sekerpare clones were evaluated and the results are presented in Table 5. Amongst the 18 clones of Sekerpare cultivar, the KS15 clone showed the lowest antioxidant activity $(1.88 \mu \mathrm{mol} \mathrm{TE} / \mathrm{g})$, whereas the KS2 clone showed the highest antioxidant activity $(2.16 \mu \mathrm{mol} \mathrm{TE} / \mathrm{g})($ Table 5). The KS6 clone showed the second highest antioxidant activity $(2.12 \mu \mathrm{mol} \mathrm{TE} / \mathrm{g})$ and the clones KS7 and KS12 showed the third highest antioxidant activity $(2.09 \mu \mathrm{mol}$ TE/g). In Italy, among the apricot cultivars analyzed, the variability of the antioxidant capacity was obtained showing a range from 1.36 to $4.55 \mu \mathrm{mol} \mathrm{TE} / \mathrm{g}$. They found that the latest cultivars had two-fold higher TEAC values with respect to the earliest ones [68].

Previous studies conducted in different horticultural plants indicated that horticultural crops rich for antioxidant components and antioxidant activity were found to be cultivar/genotype/clone dependent [69-80].

\section{Conclusions}

A detailed morphological, nutritional and nutraceutical traits analysis was reported here for the first time in a large number of clones of $\mathrm{cv}$. Sekerpare. The results indicated that even in a small single growing location, Sekerpare clones showed rich diversity on most of the morphological traits and nutritional and nutraceutical compositions. The KS3 clone showed the highest fruit weight as $27.11 \mathrm{~g}$. KS2, KS7 and KS12 had the highest antioxidant activity. The promising clones could be used as breeding material. The results could have practical implications for orchard management to select better Sekerpare clones and bring them into production.

Author Contributions: Conceptualization, N.K., S.E. and M.R.B.; data curation, N.K., S.E. and M.R.B.; formal analysis, N.K., S.E. and M.R.B.; methodology, N.K., S.E. and M.R.B.; visualization, S.E.; writing—original draft, N.K., S.E. and M.R.B.; writing—review and editing, N.K., S.E. and M.R.B. All authors have read and agreed to the published version of the manuscript.

Funding: No external funding for this research.

Institutional Review Board Statement: Not applicable.

Informed Consent Statement: Not applicable.

Data Availability Statement: All new research data were presented in this contribution.

Conflicts of Interest: The authors declare that they have no conflict of interest.

\section{References}

1. FAO. Food and Agriculture Organization of the United Nations. 2020. Available online: http://www.fao.org/faostat/en/\#data/ QC (accessed on 18 April 2021).

2. Ercisli, S. Apricot culture in Turkey. Sci. Res. Essays 2009, 4, 715-719.

3. Ruiz, D.; Egea, J. Phenotypic diversity and relationships of fruit quality traits in apricot (Prunus armeniaca L.) germplasm. Euphytica 2008, 163, 143-158. [CrossRef]

4. Karatas, N.; Sengul, M. Some important physicochemical and bioactive characteristics of the main apricot cultivars from Turkey. Turk. J. Agric. For. 2020, 44, 651-661. [CrossRef]

5. Gurrieri, F.; Audergon, J.M.; Albagnac, G.; Reich, M. Soluble sugars and carboxylic acids in ripe apricot fruit as parameters for distinguishing different cultivars. Euphytica 2001, 117, 183-189. [CrossRef] 
6. Munzuroglu, O.; Karatas, F.; Geckil, H. The vitamin and selenium contents of apricot fruit of different varieties cultivated in different geographical regions. Food Chem. 2003, 83, 205-212. [CrossRef]

7. Hegedus, A.; Engel, R.; Abranko, L.; Balogh, E.; Blazovics, A.; Herman, R.; Halasz, J.; Ercisli, S.; Pedryc, A.; Stefanovits-Banyai, E. Antioxidant and antiradical capacities in apricot (Prunus armeniaca L.) fruits: Variation from genotypes, years, and analytical methods. J. Food Sci. 2010, 75, C722-C730. [CrossRef]

8. Sochor, J.; Zitka, O.; Skutkova, H.; Pavlik, D.; Babula, P.; Krska, B.; Horna, A.; Adam, V.; Kizek, R.; Provaznik, I. Content of phenolic compounds and antioxidant capacity in fruits of apricot genotypes. Molecules 2010, 15, 6285-6305. [CrossRef]

9. Ali, S.; Masud, T.; Abbasi, K.S. Physico-chemical characteristics of apricot (Prunus armeniaca L.) grown in Northern Areas of Pakistan. Sci. Hortic. 2011, 130, 386-392. [CrossRef]

10. Karaat, F.E.; Serce, S. Total phenolics, antioxidant capacities and pomological characteristics of 12 apricot cultivars grown in Turkey. Adyütayam 2019, 7, 46-60.

11. Kayran, S.; Doymaz, I. Drying of Cataloglu apricots: The effect of sodium metabisulfite solution on drying kinetics, diffusion coefficient, and color parameters. Int. J. Fruit Sci. 2021, 21, 270-283. [CrossRef]

12. Gundogdu, M. Effect of rootstocks on phytochemical properties of apricot fruit. Turk. J. Agric. For. 2019, 43, 1-10. [CrossRef]

13. Pennone, F.; Abbate, V. Prospettive per la valorizzazione della coltura dell'albicocco nel Mezzogiorno attraverso il miglioramento genetico. Riv. Fruttic. Ortofloric. 2004, 66, 36-39.

14. Asma, B.; Kan, T.; Birhanli, O. Characterization of promising apricot (Prunus armeniaca L) genetic resources in Malatya, Turkey. Genet. Resour. Crop Evol. 2007, 54, 205-212. [CrossRef]

15. Molaie, S.; Soleimani, A.; Zeinolabedini, M. Evaluation of quantitative and qualitative traits of some apricot cultivars grown in Zanjan region. J. Hortic. Sci. 2016, 30, 35-48.

16. Alajil, O.; Sagar, V.R.; Kaur, C.; Rudra, S.G.; Sharma, R.R.; Kaushik, R.; Verma, M.K.; Tomar, M.; Kumar, M.; Mekhemar, M. Nutritional and phytochemical traits of apricots (Prunus armeniaca L.) for application in nutraceutical and health industry. Foods 2021, 10, 1344. [CrossRef]

17. Atis, E.; Celikoglu, S. Apricot producing in Kagizman district and its contribution to the economy of territory. Marmara Geogr. J. 2017, 36, 191-205.

18. Gecer, M.K.; Kan, T.; Gundogdu, M.; Ercisli, S.; Ilhan, G.; Sagbas, H.I. Physicochemical characteristics of wild and cultivated apricots (Prunus armeniaca L.) from Aras valley in Turkey. Genet. Resour. Crop Evol. 2020, 67, 935-945. [CrossRef]

19. Karatas, N. Some important fruit characteristics of apricot (cv. Aprikoz) accessions grown in Kagizman district in Turkey. J. Inst. Sci. Technol. 2021, 11, 1176-1182. [CrossRef]

20. Engin, S.P.; Mert, C. The effects of harvesting time on the physicochemical components of aronia berry. Turk. J. Agric. For. 2020, 44, 361-370. [CrossRef]

21. Skender, A.; Kurtovic, M.; Drkenda, P.; Becirspahic, D.; Ebrahimi, A. Phenotypic variability of autochthonous walnut (Juglans regia L) genotypes in northwestern Bosnia and Herzegovina. Turk. J. Agric. For. 2020, 44, 517-525. [CrossRef]

22. Mohsenin, N.N. Physical Properties of Plant and Animal Materials; Gordon and Breach Science Publisher: New York, NY, USA, 1986.

23. Ozturk, I.; Ercisli, S.; Kalkan, F.; Demir, B. Some chemical and physico-mechanical properties of pear cultivars. Afr. J. Biotechnol. 2009, 8, 687-693.

24. Singleton, V.L.; Rossi, J.A. Colorimetry of total phenolics with phosphomolybdic-phosphotungstic acid reagents. Am. J. Enol. Vitic. $1965,16,144-158$.

25. Bevilacqua, A.E.; Califano, A.N. Determination of organic acids in dairy products by high performance liquid chromatography. J. Food Sci. 1989, 54, 1076-1079. [CrossRef]

26. Melgarejo, P.; Salazar, D.M.; Artes, F. Organic acids and sugars composition of harvested pomegranate fruits. Eur. Food Res. Technol. 2000, 211, 185-190. [CrossRef]

27. Roussos, P.A.; Sefferou, V.; Denaxa, N.K.; Tsantili, E.; Stathis, V. Apricot (Prunus armeniaca L.) fruit quality attributes and phytochemicals under different crop load. Sci. Hortic. 2011, 129, 472-478. [CrossRef]

28. Lichtenthaler, H.K. Chlorophylls and carotenoids: Pigments of photosynthetic biomembranes. Methods Enzymol. 1987, 148, 350-382.

29. Evans, R.H.; Van Soestbergen, A.W.; Ristow, K.A. Evaluation of apple juice authenticity of organic acid analysis. J. Assoc. Off. Anal. Chem. 1983, 66, 1517-1520. [CrossRef]

30. Akca, Y.; Askin, A. Clonal selection in apricot cultivar Hacihaliloglu. Acta Hortic. 1995, 384, 169-171. [CrossRef]

31. Asma, B.M.; Ozturk, K. Analysis of morphological, pomological and yield characteristics of some apricot germplasm in Turkey. Genet. Resour. Crop Evol. 2005, 52, 305-313. [CrossRef]

32. Yilmaz, K.U.; Paydas Kargi, S.; Kafkas, S. Morphological diversity of the Turkish apricot (Prunus armeniaca L.) germplasm in the Irano-Caucasian ecogeographical group. Turk. J. Agric. For. 2010, 36, 688-694.

33. Akin, E.B.; Karabulut, I.; Topcu, A. Some compositional properties of main Malatya apricot (Prunus armeniaca L.) varieties. Food Chem. 2008, 107, 939-948. [CrossRef]

34. Akca, Y.; Asma, B.M. Clonal selection from cv. Kabasi apricot. Turk. J. Agric. For. 1997, 21, 519-521.

35. Polat, A.A.; Yilmaz, M. Investigations on the adaptations of some native and foreign apricot cultivars to Adana ecological conditions. J. Sci. Eng. 1988, 2, 127-146. 
36. Polat, A.A.; Durgac, C.; Kamiloglu, O.; Caliskan, O. Investigation on the adaptation of some low-chill apricot cultivars to Kirikhan (Turkey) ecological conditions. Acta Hortic. 2004, 636, 395-400. [CrossRef]

37. Miloševic, T.; Miloševic, N.; Glišic, I.; Glišic, I.S. Determination of size and shape properties of apricots using multivariate analysis. Acta Sci. Pol. Hortorum Cultus 2014, 13, 77-90.

38. Abd El Abd El-Rzek, E.; Abd El-Migeed, M.M.M.; Abdel-Hamid, N. Effect of spraying garlic extract and olive oil on flowering behavior, yield and fruit quality of 'Canino' apricot trees. Am.-Eur. J. Agric. Environ. Sci. 2011, 11, 776-781.

39. Peavey, M.; Goodwin, I.; McClymont, L.; Chandra, S. Effect of shading on red colour and fruit quality in blush pears "ANP-0118" and "ANP-0131". Plants 2020, 9, 206. [CrossRef]

40. Dobrzański, B.; Rybczyński, R. Colour change of apple as a result of storage, shelf-life, and bruising. Int. Agrophys. 2002, 16, 261-268.

41. Karaat, F.E. Variation and Heritability of Phytochemical Characters in Some Apricot Cultivars and Hybrids; Graduate School of Natural and Applied Sciences, Department of Agricultural Genetic Engineering, Nigde Omer Halisdemir University: Niğde, Turkey, 2018; p. 88.

42. Xi, W.; Feng, J.; Liu, Y.; Zhang, S.; Zhao, G. The R2R3-MYB transcription factor PaMYB10 is involved in anthocyanin biosynthesis in apricots and determines red blushed skin. BMC Plant Biol. 2019, 19, 287. [CrossRef]

43. Yuan, H.; Zhang, J.X.; Nageswaran, D.; Li, L. Carotenoid metabolism and regulation in horticultural crops. Hortic Res. 2015, 2, 15036. [CrossRef]

44. Saridas, M.A.; Agcam, E. Detailed fruit quality contents of 'Teberze' and 'Ağerik' apricot (Prunus armeniaca L.) cultivars grown in Iğdır province. Harran J. Agric. Food Sci. 2021, 25, 214-224.

45. Imrak, B.A.; Küden, V.; Yurtkulu, E.; Kafkas, S.; Ercişli, S.; Kafkas, E. Evaluation of some phenological and biochemical characteristics of selected new late flowering dried apricot cultivars. Biochem. Genet. 2017, 55, 234-243. [CrossRef]

46. Su, C.; Zheng, X.; Zhang, D.; Chen, Y.; Xiao, J.; He, Y.; Shi, X. Investigation of sugars, organic acids, phenolic compounds, antioxidant activity and the aroma fingerprint of small white apricots grown in Xinjiang. J. Food Sci. 2020, 85, 4300-4311. [CrossRef]

47. Schmitzer, V.; Slatnar, A.; Mikulic-Petkovsek, M.; Veberic, R.; Krska, B.; Stampar, F. Comparative study of primary and secondary metabolites in apricot (Prunus armeniaca L.) cultivars. J. Sci. Food Agric. 2011, 91, 860-866. [CrossRef]

48. Melgarejo, P.; Calín-Sánchez, Á.; Carbonell-Barrachina, Á.A.; Martínez-Nicolás, J.J.; Legua, P.; Martínez, R.; Hernández, F. Antioxidant activity, volatile composition and sensory profile of four new very early apricots (Prunus armeniaca L.). J. Sci. Food Agric. 2014, 94, 85-94. [CrossRef]

49. Fan, X.; Zhao, H.; Wang, X.; Cao, J.; Jiang, W. Sugar and organic acid composition of apricot and their contribution to sensory quality and consumer satisfaction. Sci. Hortic. 2017, 225, 553-560. [CrossRef]

50. Pereira, C.; Barros, L.; Carvalho, A.M.; Ferreira, I.C. Use of UFLC-PDA for the analysis of organic acids in thirty-five species of food and medicinal plants. Food Anal. Methods 2013, 6, 1337-1344. [CrossRef]

51. Bae, H.; Yun, S.K.; Yoon, I.K.; Nam, E.Y.; Kwon, J.H. Assessment of organic acid and sugar composition in apricot, plumcot, plum, and peach during fruit development. J. Food Qual. Appl. Bot. 2014, 87, 24-29.

52. Cirilli, M.; Baccichet, I.; Chiozzotto, R.; Spinardi, A.; Bassi, D. Organic acids content in fruit flesh and skin from a large apricot collection. Acta Hortic. 2020, 1290, 197-200. [CrossRef]

53. Colaric, M.; Veberic, R.; Stampar, F.; Hudina, M. Evaluation of peach and nectarine fruit quality and correlations between sensory and chemical attributes. J. Sci. Food Agric. 2005, 85, 2611-2616. [CrossRef]

54. Saeed, I.; Guo, X.; Azeem, M.; Elshikh, M.S.; Zainab, B.; Ayaz, Z.; You, L.; Alwahibi, M.S.; Abbasi, A.M. Comparative assessment of polyphenolics' content, free radicals' scavenging and cellular antioxidant potential in apricot fruit. J. King Saud Univ.-Sci. 2021, 33, 101459. [CrossRef]

55. Çaliskan, O.; Bayazit, S.; Sumbul, A. Fruit quality and phytochemical attributes of some apricot (Prunus armeniaca L.) cultivars as affected by genotypes and seasons. Not. Bot. Hortic. Agrobot. Cluj-Napoca 2012, 40, 284-294. [CrossRef]

56. Wani, A.A.; Zargar, S.A.; Malik, A.H.; Kashtwari, M.; Nazir, M.; Khuroo, A.A.; Ahmad, F.; Dar, T.A. Assessment of variability in morphological characters of apricot germplasm of Kashmir, India. Sci. Hortic. 2017, 225, 630-637. [CrossRef]

57. Leccese, A.; Bartolini, S.; Viti, R. From cultivar to apricot fruit quality: The antioxidant properties contribution. Plant Food Hum. Nutr. 2012, 67, 317-325. [CrossRef]

58. Carbone, K.; Ciccoritti, R.; Paliotta, M.; Rosato, T.; Terlizzi, M.; Cipriani, G. Chemometric classification of early-ripening apricot (Prunus armeniaca L.) germplasm based on quality traits, biochemical profiling and in vitro biological activity. Sci. Hortic. 2018, 227, 187-195. [CrossRef]

59. Kafkaletou, M.; Kalantzis, I.; Karantzi, A.; Christopoulos, M.V.; Tsantili, E. Phytochemical characterization in traditional and modern apricot (Prunus armeniaca L.) cultivars-Nutritional value and its relation to origin. Sci. Hortic. 2019, 253, 195-202. [CrossRef]

60. Yamada, T.; Hayasaka, S.; Shibata, Y.; Ojima, T.; Saegusa, T.; Gotoh, T.; Ishikawa, S.; Nakamura, Y.; Kayaba, K. Frequency of citrus fruit intake is associated with the incidence of cardiovascular disease: The Jichi Medical School cohort study. J. Epidemiol. 2011, 21, 169-175. [CrossRef]

61. Giampieri, F.; Tulipani, S.; Alvarez-Suarez, J.M.; Quiles, J.L.; Mezzetti, B.; Battino, M. The strawberry: Composition, nutritional quality, and impact on human health. Nutrition 2012, 28, 9-19. [CrossRef] 
62. McCullough, M.L.; Peterson, J.J.; Patel, R.; Jacques, P.F.; Shah, R.; Dwyer, J.T. Flavonoid intake and cardiovascular disease mortality in a prospective cohort of US adults. Am. J. Clin. Nutr. 2012, 95, 454-464. [CrossRef]

63. Singh, M.; Suman, S.; Shukla, Y. New enlightenment of skin cancer chemoprevention through phytochemicals: In vitro and in vivo studies and the underlying mechanisms. Biomed. Res. Int. 2014, 243452.

64. Rodríguez-Morató, J.; Xicota, L.; Fitó, M.; Farré, M.; Dierssen, M.; De la Torre, R. Potential role of olive oil phenolic compounds in the prevention of neurodegenerative diseases. Molecules 2015, 20, 4655-4680. [CrossRef] [PubMed]

65. Ruiz, D.; Egea, J.; Tomás-Barberán, F.A.; Gil, M.I. Carotenoids from new apricot (Prunus armeniaca L.) varieties and their relationship with flesh and skin colour. J. Agric. Food Chem. 2005, 53, 6368-6374. [CrossRef]

66. Shemesh, K.; Zohar, M.; Bar-Yaakov, I.; Hatib, K.; Holland, D.; Isaacson, T. Analysis of carotenoids in fruit of different apricot accessions reveals large variability and highlights apricot as a rich source of phytoene and phytofluene. Fruits 2017, 72, 185-202. [CrossRef]

67. Fratianni, F.; Ombra, M.N.; d'Acierno, A.; Cipriano, L.; Nazzaro, F. Apricots: Biochemistry and functional properties. Curr. Opin. Food Sci. 2018, 19, 23-29. [CrossRef]

68. Leccese, A.; Bartolini, S.; Viti, R. Total antioxidant capacity and phenolics content in fresh apricots. Acta Aliment. 2008, 37, 65-76. [CrossRef]

69. Zia-Ul-Haq, M.; Ahmad, S.; Qayum, M.; Ercisli, S. Compositional studies and antioxidant potential of Albizia lebbeck (L.) Benth. Pods and seeds. Turk. J. Biol. 2013, 37, 25-32.

70. Bolat, I.; Dikilitas, M.; Ercisli, S.; Ikinci, A.; Tonkaz, T. The effect of water stress on some morphological, physiological, and biochemical characteristics and bud success on apple and quince rootstocks. Sci. World J. 2014, 2014, 769732. [CrossRef]

71. Dogan, H.; Ercisli, S.; Jurikova, T.; Temim, E.; Leto, A.; Hadziabulic, A.; Tosun, M.; Narmanlioglu, H.K.; Zia-Ul-Haq, M. Physicochemical and antioxidant characteristics of fruits of cape gooseberry (Physalis peruviana L.) from Turkey. Oxid. Commun. 2014, 37, 1005-1014.

72. Dogan, H.; Ercisli, S.; Temim, E.; Hadziabulic, A.; Tosun, M.; Yilmaz, S.O.; Zia-Ul-Haq, M. Diversity of chemical content and biological activity in flower buds of a wide number of wild grown caper (Capparis ovate Desf.) genotypes from Turkey. C. R. Acad. Bulg. Sci. 2014, 67, 1593-1600.

73. Gundogdu, M.; Ozrenk, K.; Ercisli, S.; Kan, T.; Kodad, O.; Hegedus, A. Organic acids, sugars, vitamin C content and some pomological characteristics of eleven hawthorn species (Crataegus spp.) from Turkey. Biol. Res. 2014, 47, 21. [CrossRef]

74. Ersoy, N.; Kupe, M.; Sagbas, H.I.; Ercisli, S. Phytochemical diversity among barberry (Berberis vulgaris L.). Not. Bot. Horti Agrobo. 2018, 46, 198-204. [CrossRef]

75. Ersoy, N.; Kupe, M.; Gundogdu, M.; Gulce, I.; Ercisli, S. Phytochemical and antioxidant diversity in fruits of currant (Ribes spp.) cultivars. Not. Bot. Horti Agrobo. 2018, 46, 381-387. [CrossRef]

76. Ozkan, G. Phenolic compounds, organic acids, vitamin C and antioxidant capacity in Prunus spinose. C. R. Acad. Bulg. Sci. 2019, 72, 267-273.

77. Göttingerová, M.; Kumšta, M.; Nečas, T. Health-benefitting biologically active substances in edible apricot flowers. HortScience 2020, 55, 1372-1377. [CrossRef]

78. Ozkan, G.; Ercisli, S.; Sagbas, H.I.; Ilhan, G. Diversity on fruits of wild grown European cranberrybush from Coruh valley in Turkey. Erwerbs-Obstbau 2020, 62, 275-279. [CrossRef]

79. Bujdosó, G.; Cseke, K. The Persian (English) walnut (Juglans regia L.) assortment of Hungary: Nut characteristics and origin. Sci. Hortic. 2021, 283, 110035. [CrossRef]

80. Rampáčková, E.; Göttingerová, M.; Gála, P.; Kiss, T.; Ercişli, S.; Nečas, T. Evaluation of protein and antioxidant content in apricot kernels as a sustainable additional source of nutrition. Sustainability 2021, 13, 4742. [CrossRef] 